\title{
ROLE OF FIRE EPISODE, LEAF LITTER DECOMPOSITION AND MULCHING EFFECTS IN RESTORATION OF THE SURFACE SOIL CRUST MICROECOSYSTEM ON ABANDONED TAILINGS CONTAINMENT
}

\author{
Michal ŠTeFÁNeK ${ }^{1}$, PAVEl KovÁŘ ${ }^{1}$, VeroniKa DlOUHÁ $^{2}$ \\ ${ }^{I}$ Department of Botany, Charles University, Benátská 2, CZ-128 01 Prague 2, Czech \\ Republic \\ ${ }^{2}$ Museum of Central Bohemia in Roztoky, Zámek 1, CZ-252 63 Roztoky u Prahy, Czech \\ Republic
}

Received: $16^{\text {th }}$ November 2012, Accepted: $18^{\text {th }}$ December 2012

\begin{abstract}
This article examines the consequences of a fire (August 1994) which burned the vegetated surface of abandoned tailings containment in mosaic pattern, in Chvaletice (Eastern River Elbe basin, Czech Republic). Vegetation succession with adjacent processes (such as leaf litter decomposition) was then monitored in comparisons on burned and unburned plots. The influence of the introduced plant organic matter by mulching on the biological soil crust was also investigated. Apart from the naturally burned plots, some plots were also experimentally burned. The soil moisture and surface temperatures in different temporal distances from the fire experiment were measured. There were no significant differences in decomposition rate between the plots that were affected and/or unaffected by fire. The daily temperatures of the burned soil surface increased after the fire, while its night temperatures decreased. The moisture content of the soil surface was reduced after the fire. Addition of dry local aboveground plant biomass on the substrate surface suggests that substrate roughness provides retention to seeds transported by wind, and protects the rhizosphere against extreme heat, drought and salt incrustation. Furthermore, it positively modifies the hydrological regime of microsites and stimulates the creation of a humus soil layer and enrichment of the substrate by nutrients. Finally, it facilitates colonisation by plant seedlings from seeds transported by anemochorous or zoochorous mechanisms.
\end{abstract}

Keywords: Vegetation succession, abandoned tailings containment, biological soil crust, surface microecosystems, substrate toxicity, salinity, soil moisture, temperature measurement, fire disturbance, environmental stress, plant litter decomposition, ecological restoration

\section{INTRODUCTION}

The study of spontaneous vegetation succession on anthropogenous habitats in long-term scale is not usual, despite the fact that there are many places with industrial and mining activity where new landforms and/or substrates are opened and exposed to organismal 
colonization. Studies of the primary (in some cases secondary) succession are placed on dumps of mine refuse, derived from brown coal (e.g., Prach et al. 2008) and black coal mining, ore mining (e.g., Frouz et al. 2008) or dumps for fly ash from power stations (e.g., Kovář et al. 2004).

The ecotoxicological aspect of the site plays an important role in its reclamation (Kovár 1979, 1990). The high heavy metal concentrations, extreme $\mathrm{pH}$ values, and high sulphur and phenol contents of the substrate, complicate spontaneous processes leading to natural recovery (Vos \& Opdam 1993, Kováŕ et al. 2011). Soil development greatly varies over the basin, according to its microtopography determined by oxidation of sulphides and leaching of salts. The substrate surface is typically fragmented by patches of salt efflorescences from gypsum and jarosite; secondary salt accumulation is determined by the length of dry periods in the vegetation season. A strongly cemented horizon, with red ferric oxides and gypsum, develops at lower depths of soil profiles (Rauch 2004).

The industrial deposit system in Chvaletice consists of three tailings (ore-washery sedimentation basins) as a result of former pyrite ore mining. A surface mine was opened here in 1952. Sulphidic gneisses and carbonate Fe-Mn ore deposits were the main waste material originating as a by-product of sulphuric acid production. This waste material was transported as sludge (mixed with water) to sedimentation basins. After the basin had been filled up, dikes were built around it to fill the artificial basin with more sludge. This was repeated several times thus creating a final body of industrial deposits $18 \mathrm{~m}$ high (Kovár 2004). The quarry in Chvaletice was closed indefinitely in the mid-1970s, after which the two older tailings were reclaimed in a conventional way (partly agriculturally, partly by tree planting; Kováŕ 1979). The third, youngest basin has never been filled up completely and its surface has remained unreclaimed since the early 1980s, and has become an important experimental object for the monitoring and testing of spontaneous colonisation of the deposited substrate (Kováŕ 2004).

The non-reclaimed basin has therefore remained largely treeless or non-vegetated and no manipulations were carried out after abandonment. The vascular plant diversity is usually low in this toxic environment (Vaňková \& Kovář 2004). In such places, the surface is often covered with biological soil crusts, originating spontaneously and representing analogies to similar crusts frequent in semi-arid and desert environments (Evans \& Johansen 1999, Hroudová \& Zákravský 2004). Both types of crust are usually composed of fungal mycelia, cyanobacteria, algae, lichens, mosses and liverworts (Neustupa et al. 2009). The initial state of the substrate surface resists colonisation by vascular plants (Pohlová 2004, Palice \& Soldán 2004) because its roughness is insufficient (extremely low interception and retention capacity for plant seeds transported by wind) and a humus soil layer is missing (absence of biotic nitrogen and carbon fixation).

The activity on the third sedimentation basin in Chvaletice ended in the beginning of the 1980's. Of all the three dumps, only this one was not recultivated and was left to spontaneous succession with the above-mentioned disruption of the fire episode in 1994 (Kovár et al. 2011). This disturbance became the beginning of secondary succession. Because the fire did not hit the whole area of the sedimentation basin, it was possible to compare the processes of primary and secondary succession within the same habitat. A general question reflecting the needs of restoration practice follows: How effective is the introduction of dead herbal biomass to the bare surface of a non-reclaimed tailing, in terms of colonisation/succession speed, species diversity and facilitation of natural processes? 


\section{MATERIAL AND METHODS}

\section{Character of the locality}

Geographical location: Elbe river lowland near Chvaletice, Eastern Bohemia, Czech Republic; $50^{\circ} 02^{\prime} \mathrm{N}, 15^{\circ} 26^{\prime} \mathrm{E}$; altitude $200 \mathrm{~m}$. Area under natural restoration: 40 ha. Habitat parameters: The non-reclaimed basin has remained largely treeless or non-vegetated and no manipulations were carried out after abandonment (across the total surface area in 1984). In the genesis of acid sulphate soils, chemical processes prevail over the role of vegetation, which is reflected in major adverse characteristics of the soil profiles (Kovár 1979).

\section{Comparison of the litter decomposition rate}

The litter-bag method was used to assess the rate of decomposition (Suffling \& Smith 1974, Tesařová 1987). Material was dried and stored at room temperature during the winter. The following type of material was compared: leaves of Populus tremula, leaves of Betula pendula, aboveground parts of Calamagrostis epigejos (leaves and stems) and the cellulose (filter paper). Before the start of the experiment, this material was dried at $60^{\circ} \mathrm{C}$ for 24 hours. Dried and weighed material was put inside the litter bags.

On the sedimentation pond in Chvaletice a relatively homogeneous stand was chosen, comprising the dominant grass species Calamagrostis epigejos and tree species (aspen Populus tremula and birch Betula pendula). Twelve plots (size 2 × $2 \mathrm{~m}$ ) not touching each other were arbitrarily chosen, and six of these plots were burned in May 1998. Twenty litter bags with the four types of the material in five replicates were laid on the surface in the middle of each these plots, where the fire intensity was greatest, and then sampled six times in 1998. After sampling, litter bags were cleaned and dried at $60{ }^{\circ} \mathrm{C}$ for 24 hours. Material was then taken out of the litter bags and weighed.

Relative rate of decomposition was counted using this equation:

$\mathrm{RDR}=1000 \mathrm{x}(\mathrm{I}-/ \mathrm{F}-\mathrm{S} /) /(\mathrm{IxT})$, where RDR - the relative rate of decomposition $(\mathrm{mg} / \mathrm{g} \mathrm{x}$ day of exposition), I - starting weight (g), F - ending weight (g), S - spillage (g), T - time of exposition (days).

Starting weight I was the weight at the start of the experiment, ending weight $F$ was the weight at the end of experiment. The time of the exposition $\mathrm{T}$ was 171 days (May November). The spillage means losses due to fallout of the material from litter-bags. Litterbags with this mesh size had immeasurable spillage (Medonosová 1984), spillage was thus considered to be null. A statistical comparison of the rate of undecomposed biomass (at the end of experiment in different material) was made using a two-way analysis of variance model with non-variable effects (Lepš 1996). Independent variables were decomposed material and treatment (fire, without fire), whilst the dependent variable was the remaining undecomposed material.

\section{Comparison of microclimate parameters}

Four soil samples were collected and temperature variation during twenty four hours was measured in each of three plots, which were established within a relatively homogeneous stand of Calamagrostis epigejos (in 1999). Plot no. 1 was left without any treatment, plot no. 2 was burned on 18 May 1998; its dominant species at the time of observation was also Calamagrostis epigejos, but its cover was not so high as in the previous case and mosses occured rarely. Plot no. 3 was burned one day before the experiment (July 24, 1999) so that there was no vegetation on this plot at the time of the experiment. The temperature was measured $1 \mathrm{~cm}$ below the substrate's surface on each plot. The measurement was made every hour (excluding midnight) from 10 a.m. to 12 noon of next day. The weather prior to 
and during the experiment was 0 percent cloud cover and with high radiation. A statistical comparison of temperature differences, between plots with different treatments, was made using a paired t-test.

Samples of the soil were collected from the surface layer of the substrate into cylinders, which were dried at $105^{\circ} \mathrm{C}$ for 24 hours in a laboratory (Kubíková 1971). After drying, they were re-weighed. Water content was counted as water content in $\%$ of fresh soil weight: $\mathrm{MV}=\left(\mathrm{z}_{1}-\mathrm{z}_{2}\right) / \mathrm{z}_{1} \times 100$, where MV - actual moisture, $\mathrm{z}_{1}$ - weight of fresh soil $(\mathrm{g}), \mathrm{z}_{2}-$ weight of dry matter of soil (s). Comparison of differences in actual soil moisture on plots with different treatments (unburned plot, one day after fire, 433 days after fire, respectively) was made using a one-way analysis of variance. The independent variable was type of treatment, whereas the dependent variable was actual soil moisture (water content as a percentage of fresh soil weight).

\section{Mulching by addition of dry plant biomass}

Experimental plots were designed (1999) as paired quadrats (one treatment, one control) in eight repetitions (i.e. 16 squares $1.5 \times 1.5 \mathrm{~m}$ in size). The bare substrate surface was covered with a $10-15 \mathrm{~cm}$ thick layer of dry local herbal biomass. All plots were divided into $15 \times 15 \mathrm{~cm}$ squares for recording vegetation parameters. Abundance of the aboveground biomass was assessed (1995-1999) by means of a nine-point scale (0-8).

\section{RESULTS AND DISCUSSION}

\section{Litter decomposition}

The relative rate of the decomposition was very low (from 0.94 to $2.02 \mathrm{mg} . \mathrm{g}^{-1} . \mathrm{day}^{-1}$ ) (Table 1). Average values of the remaining undecomposed material at the end of the experiment (after 171 days of exposition) together with the graphic course of the decomposition, are shown in Figures 1-4.

Table 1: Relative decomposition rate (RDR) of various litter in burned/unburned sites

\begin{tabular}{|c|c|c|c|c|c|c|c|c|}
\hline $\begin{array}{l}\text { type of } \\
\text { material }\end{array}$ & \begin{tabular}{|c|} 
Betula \\
pendula
\end{tabular} & $\begin{array}{c}B . \\
\text { pendula }\end{array}$ & $\begin{array}{l}\text { Populus } \\
\text { tremula }\end{array}$ & $\begin{array}{c}P . \\
\text { tremula }\end{array}$ & cellulose & cellulose & $\begin{array}{c}\text { Calamagrostis } \\
\text { epigejos }\end{array}$ & C. epigejos \\
\hline treatment & fire & $\begin{array}{l}\text { without } \\
\text { fire }\end{array}$ & fire & $\begin{array}{l}\text { without } \\
\text { fire }\end{array}$ & fire & $\begin{array}{l}\text { without } \\
\text { fire }\end{array}$ & fire & $\begin{array}{l}\text { without } \\
\text { fire }\end{array}$ \\
\hline $\begin{array}{c}\text { average } \\
\text { value of } \\
\mathrm{RDR} \\
\left(\mathrm{mg} \cdot \mathrm{g}^{-1}\right. \\
\left.\text { day }^{-1}\right)\end{array}$ & 2,015 & 1,736 & 1,969 & 1,185 & 0,939 & 1,109 & 1,785 & 1,809 \\
\hline $\begin{array}{l}\text { standard } \\
\text { deviation }\end{array}$ & 0,156 & 0,558 & 0,401 & 0,454 & 0,567 & 0,495 & 0,504 & 0,2 \\
\hline
\end{tabular}


Fig. 1: Decomposition course of Betula pendula

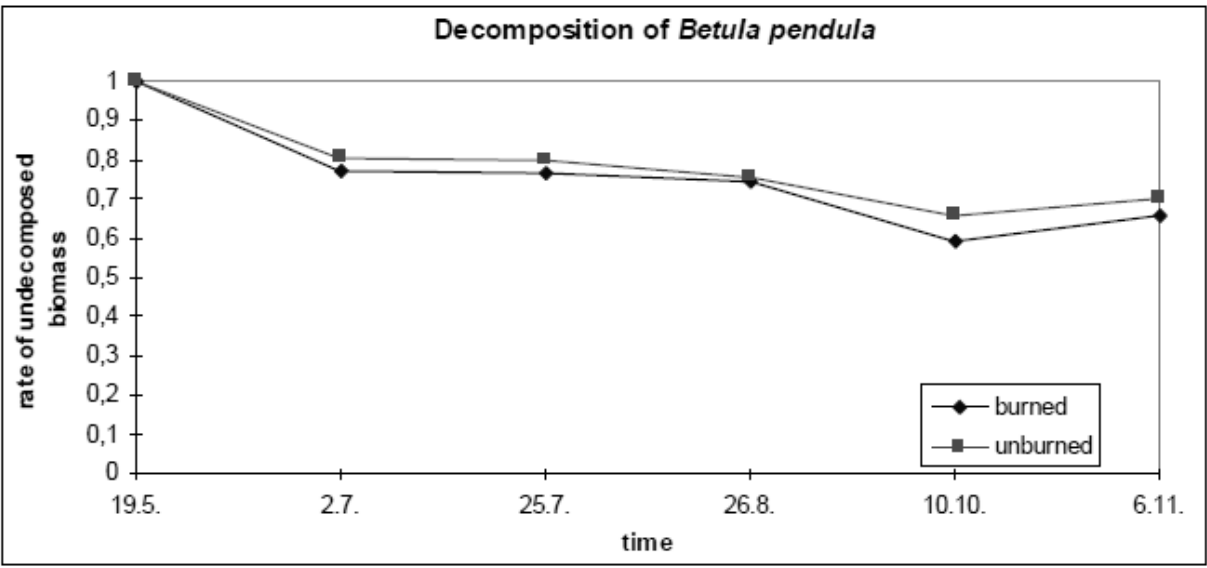

Fig. 2: Decomposition course of Populus tremula

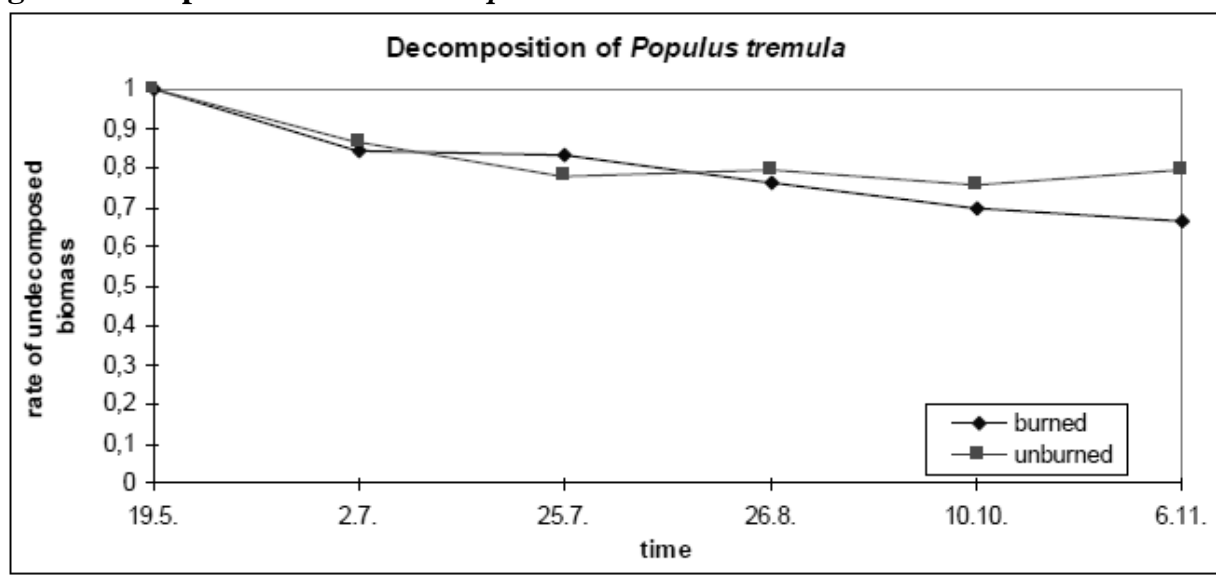

Fig. 3: Decomposition course of cellulose

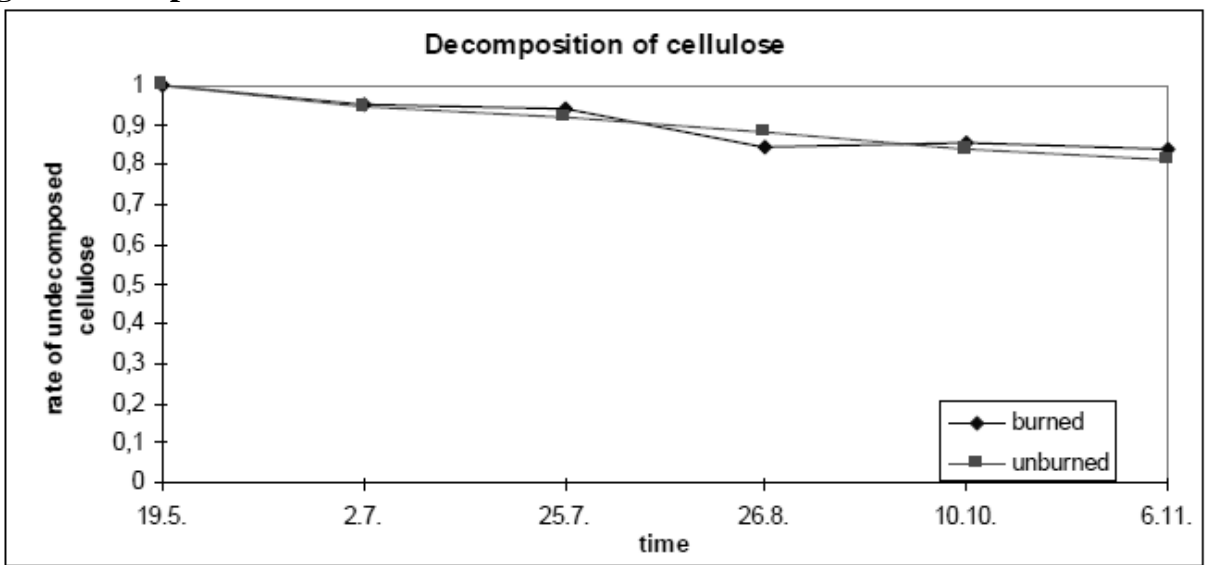


Fig. 4: Decomposition course of Calamagrostis epigejos

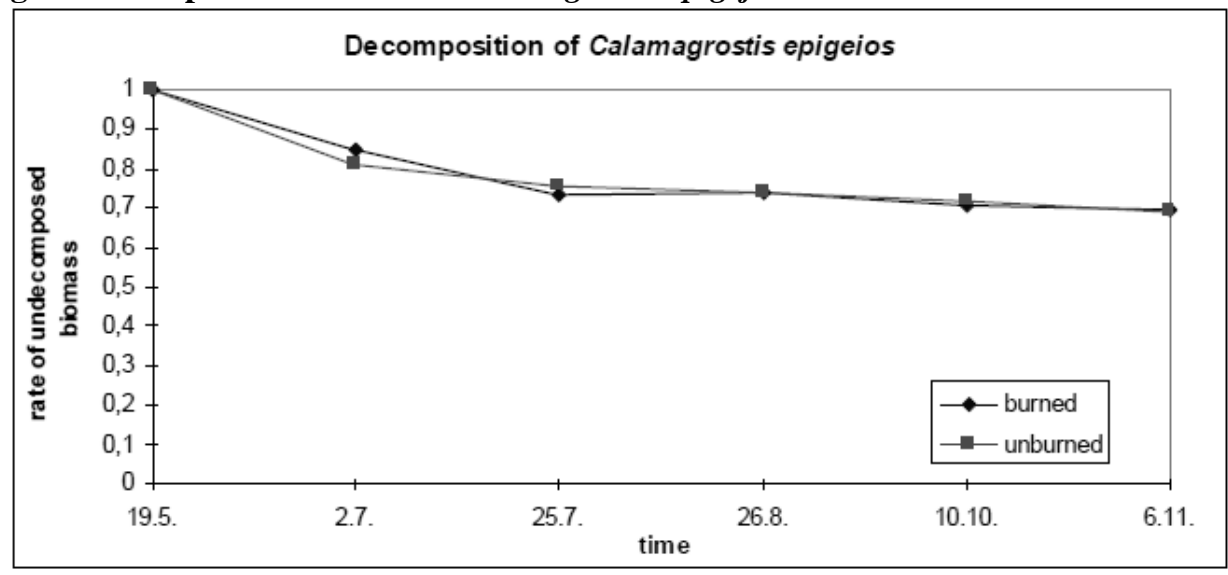

Fig. 5: Decomposition of different kinds of dead plant material on burned/ unburned sites

1 - Betula pendula / burned places

2 - Betula pendula / places without fire

3 - Populus tremula / fire places

4 - Populus tremula / places without fire
5 - cellulose / fire places

6 - cellulose / places without fire

7 - Calamagrostis epigejos / fire places

8 - Calamagrostis epigejos / places without fire

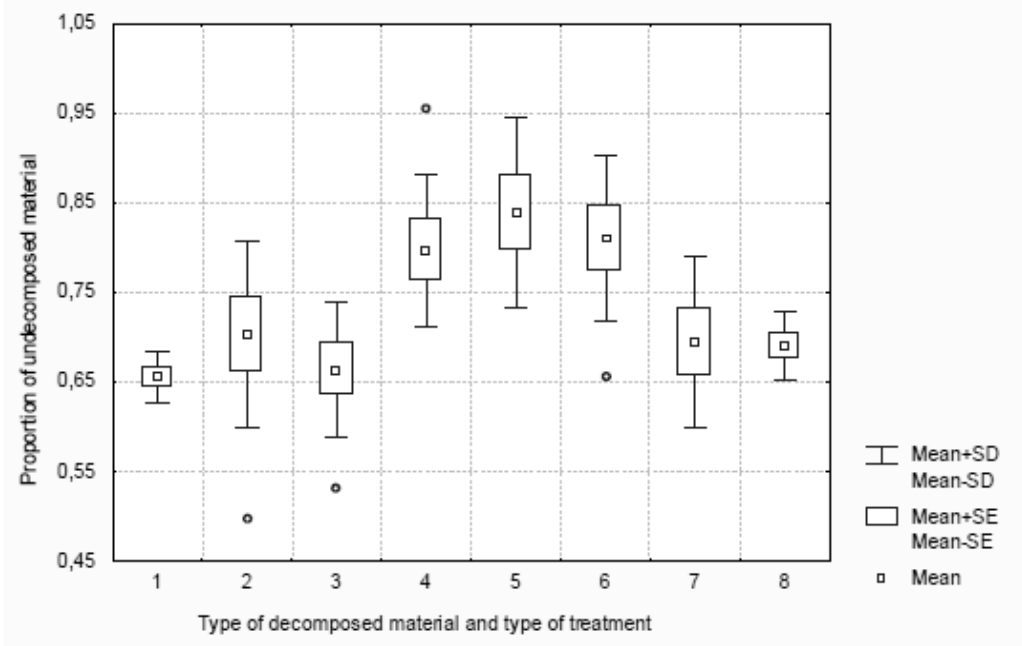

Comparison of the mean values is done in Figure 5. The null hypothesis, that the rate of decomposition on burned and unburned plots did not differ, was not rejected after statistical testing (at $\mathrm{P}<0.05$ ). In general, low RDR measured on the surface of abandoned tailings containment in Chvaletice could be caused by several unfavourable environmental factors. These factors are very low soil moisture content (Williams \& Gray 1974), and toxicity of the substrate due to high heavy metal contents (Ebregh \& Boldewijn 1977) and low pH (Singh 1977), which negatively affects activity of soil decomposers and, accordingly, the rate of decomposition. The type of material had a considerable effect on the rate of decomposition $\left(\mathrm{P}=2,58 \times 10^{-7}\right)$, see also Spěváková (2004) and Kovářová \& Frantík 
(2004). The interaction of both effects was also significant $(P=0,0385)$. Non-significant difference in the rate of decompositin between the burned and unburned plots could be explained by several factors, such as increased temperature of the soil surface thereby increasing the decomposition rates after the fire. Conversely, a decreased soil moisture content will lower the rate of decomposition (Grigall \& Mc Coll 1977).

\section{Microclimate}

The highest diurnal temperatures and the lowest nocturnal temperatures $\left(51^{\circ} \mathrm{C}\right.$ and $5.1{ }^{\circ} \mathrm{C}$, respectively) were measured on the surface of fresh fire site (the daily course of temperature is shown in Figure 6). The extreme differences between the highest and the lowest temperatures were recorded on plot no. $3\left(40.4{ }^{\circ} \mathrm{C}\right.$ at 12 p.m., $9.1{ }^{\circ} \mathrm{C}$ at 5 p.m., the difference being $31.4{ }^{\circ} \mathrm{C}$ ). The maximum temperature on the plot no. 2 was $34.1^{\circ} \mathrm{C}$ (at 15 and $16 \mathrm{o}^{\prime}$ clock), the lowest was $10.2^{\circ} \mathrm{C}$ (at $5 \mathrm{o}^{\prime}$ clock in the morning), so the difference was $23.5^{\circ} \mathrm{C}$. Relatively balanced temperatures were recorded on plot no. 1 (the difference was

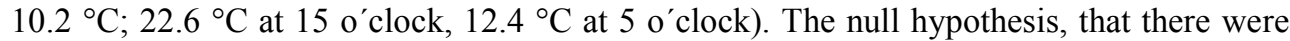
no differences between plots 1 and $2(\mathrm{P}=0.00189), 1$ and $3(\mathrm{P}=0.00047)$, and 2 and $3(\mathrm{p}=$ $0.00053)$, was rejected at $\mathrm{P}<0.005$. Hroudová \& Zákravský (2004) measured similar extreme temperatures on the abandoned sediment deposit in Chvaletice at the surface of the moss layer and on the plot without vegetation. Notably the bare surface had similar characteristics as the burned plot (dark colour of the substrate, absence of vegetation and of the litter). These atributes caused strong overheating of the soil surface. Statistical tests showed a significant effect of the fire on temperature variation. Ewing \& Engle (1988) and Hurlbert (1969) made similar observations.

Fig. 6: Daily temperatury courses $1 \mathrm{~cm}$ below the substrate surface

courses of temperature

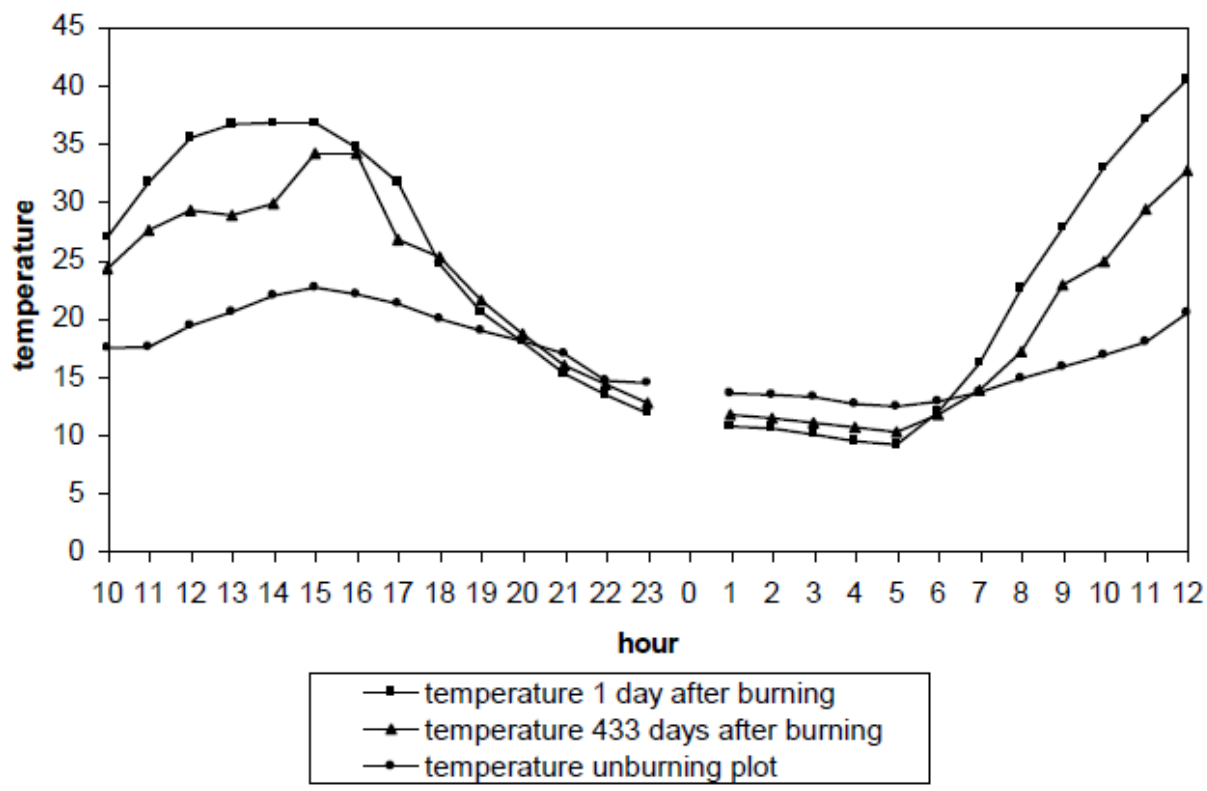


The highest soil moisture was recorded on plot 1, and the lowest soil moisture was measured on plot 2 (average values of soil moisture are shown in Table 2 and Figure 7). A statistical test (one way ANOVA) showed that there was a significant effect of treatment type on soil moisture content $(\mathrm{P}=0.0002)$. Another statistical test (Tukey test) showed significant differences in soil moisture between unburned plots and plots one day after fire $(\mathrm{P}=0,000334)$. A significant difference was also observed between unburned plots and plots 443 days after fire $(\mathrm{P}=0,001807)$. On the other hand, there was no significant difference between burned (one day and 443 days after burning) plots. The highest actual soil moisture in the surface layer was measured on the unburned plots. It was caused by relatively low temperatures of the soil surface due to the presence of a herb layer (quite dense growth of Calamagrostis epigejos) and a dense cover of mosses. The lowest actual soil moisture was measured 433 days after the fire. Somewhat higher moisture was detected on a freshly burned plots. It was probably caused by low fire intensity which did not fully desiccate the soil surface, and by the short period of lapsed time after the fire. During this short time, solar radiation and consecutively higher temperatures did not wholy remove soil water from the surface layer (Ewing \& Engle 1988). Generally, development of vegetation succession at the locality (over decades) was discussed in context of establishment of tree storey in present stands (Kovář et al. 2011). Relatively rapid vegetational recovery after the fire (in commonly retarding stressed conditions) is caused by raising physiological activity of species, sprouting stimulated by fire and/or fire-conditioned germination, flowering and seed production (Herranz et al. 1996).

Fig. 7: Comparison of the soil moisture on burned and unburned plots

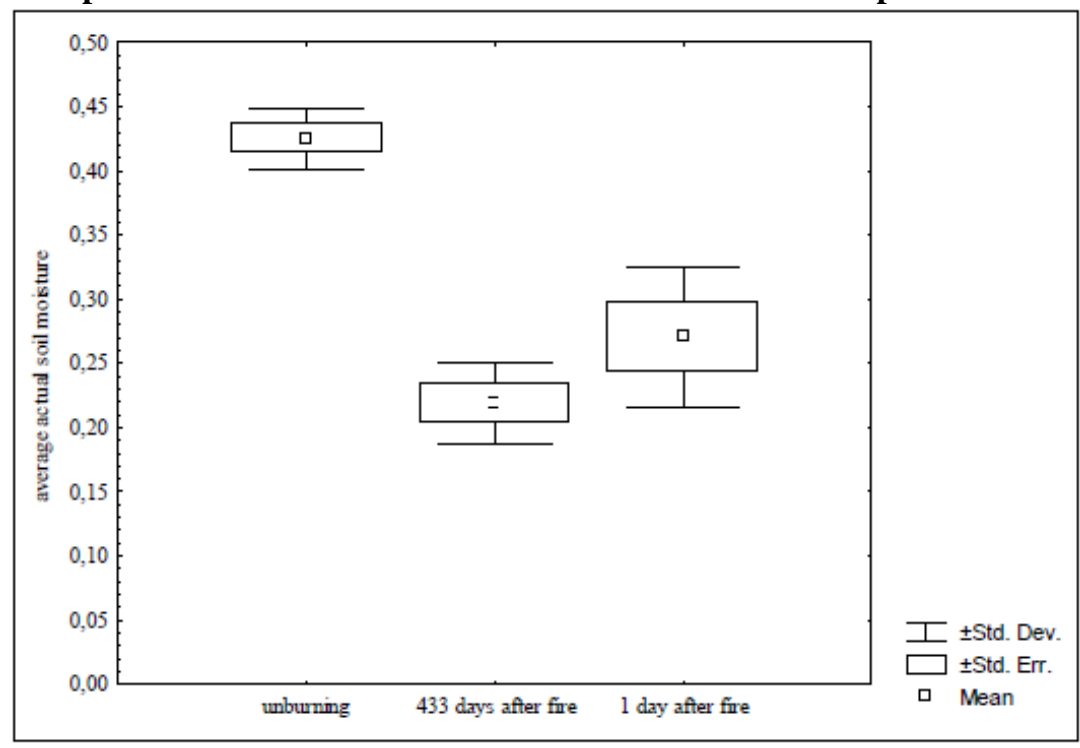


Table 2: Comparison of values of the soil moisture in burned and unburned plots

\begin{tabular}{|c|c|c|c|c|}
\hline \multicolumn{2}{|c|}{ plot } & $\begin{array}{c}\text { water } \\
\text { content in } \\
\% \text { of fresh } \\
\text { soil weight }\end{array}$ & $\begin{array}{c}\text { water } \\
\text { content in } \\
\% \text { of dry } \\
\text { matter of } \\
\text { soil }\end{array}$ & $\begin{array}{c}\text { water } \\
\text { content in } \\
\% \text { of soil } \\
\text { capacity }\end{array}$ \\
\hline \multirow{2}{*}{ unburned } & mean & 29,82 & 45,51 & 12,8 \\
\hline & $\begin{array}{l}\text { standard } \\
\text { deviation }\end{array}$ & 1,01 & 2,06 & 2,31 \\
\hline \multirow{2}{*}{$\begin{array}{l}\text { burned } 1 \text { day } \\
\text { before }\end{array}$} & mean & 21,19 & 27,05 & 12,7 \\
\hline & $\begin{array}{l}\text { standard } \\
\text { deviation }\end{array}$ & 2,87 & 4,75 & 1,12 \\
\hline \multirow{2}{*}{$\begin{array}{l}\text { burned } 433 \\
\text { days before }\end{array}$} & mean & 17,92 & 21,89 & 8,13 \\
\hline & $\begin{array}{l}\text { standard } \\
\text { deviation }\end{array}$ & 1,91 & 2,76 & 2,24 \\
\hline
\end{tabular}

\section{Mulching effects}

Plant litter, introduced on smooth substrate surface of non-reclaimed waste deposits, moderates extremes in salinity and microclimate (the results of which are shown in Figure 8). Initial retention of seeds, caused by the dry plant biomass addition by mulching, was a quick process. This was indicated by a massive presence of seedlings, predominantly of Calamagrostis epigejos. This resistant pioneer grass species uses both anemochorous and zoochorous (myrmecochorous) dispersal strategies, depending on the properties of the tailing substrate (Bryndová \& Kováŕ 2004, Jarešová \& Kovář 2004, Kovář et al. 2012). Establishment of its light seeds depends here on surface roughness (retention and fixation) and degree of microhabitat extremity. It is apparent that the initial effect is markedly dominated by Calamagrostis epigejos, due to its high frequency in the surrounding of the locality. After initial strong differences between treated and control plots, abundance of this grass shows convergence. This suggests that the observed development does not necessarily mean a negative trend towards a blocked successional stage with just this clonal grass (e.g., Prach \& Pyšek 1994). In these extreme ecological conditions, Calamagrostis epigejos plays a positive role, in contrast to other habitats such as spoil heaps after coal mining. In the second year of our experiment, seedlings of the following additional plant species were recorded in our plots: Cerastium holosteoides, Conyza canadensis, Epilobium sp., Puccinellia distans, Sonchus oleraceus, Taraxacum sect. Ruderalia, Tanacetum vulgare, Betula pendula and Populus tremula (Dlouhá 1999). The increase in species number continued during the following years, to reach a stage in which the local stand has become as high as that of the species pool in the surrounding area. The tree layer has reached a height of ca. $5 \mathrm{~m}$ (Kovár et al. 2011).

The revegetation was significantly enhanced by the organic litter cover, which protected the rhizosphere against heat, drought and salt incrustation (Rauch 2004, Hroudová \& Zákravský 2004). This creation of a biological crust was based on a synergy of two effects of the added organic material: nutrient enrichment by decomposition of dead matter (Kovářová \& Frantík 2004) and creating a vital environment for ants as distributors of zoochoric plants (Jarešová \& Kovář 2004) with a subsequent increase in plant diversity (Vaňková \& Kováŕ 2004, Kovář et al. 2012). 
Fig. 8: Course in abundance of Calamagrostis epigejos ramets after mulching the bare substrate surface. (asterisks indicate the pairs of samplings - experiment/control - with differences significant at level $P<0.01$ ).

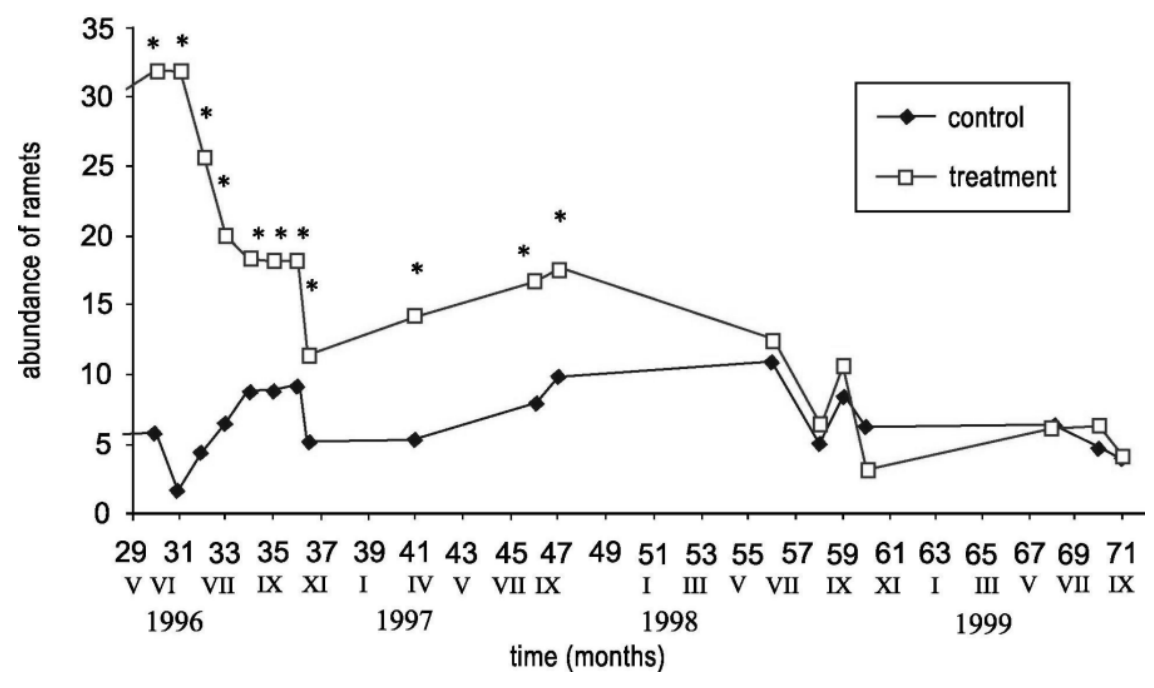

\section{CONCLUSIONS}

Monitoring of the vegetation on sedimentation basin after the formation of the mosaics of the habitats impacted by fire shows the following results:

1) rates of organic matter decomposition did not differ between burned and unburned plots,

2) actual soil moisture decreased after fire,

3) daily temperatures significantly increased after burning while the night temperatures decreased,

4) even after fire, it was possible to recognise particular successional series; higher numbers of individuals of Populus tremula, Phragmites australis and Vicia spp. were recorded on burned areas and abundance of Calamagrostis epigejos, and Betula pendula did not differ significantly between burned and unburned areas (Kovář et al. 2011).

Addition of dry local above-ground plant biomass on the tailings containment surface suggests the following functions in assisted restoration of ecologically extreme sites:

5) Mulching causes substrate roughness, providing retention to seeds transported by wind,

6) it protects the rhizosphere against extreme heat, drought and salt incrustation,

7) litter cover of the soil surface positively modifies the hydrological regime of microsites,

8) the introduced organic matter starts the creation of a humus soil layer and enrichment of the substrate by nutrients,

9) creation of a semi-biological surface layer facilitates colonisation by plant seedlings, from seeds transported by anemochorous or zoochorous mechanisms, 
10) in general, mulching is the essential factor in the development of an effective biological crust, enhancing and accelerating species diversity increase during succession.

\section{ACKNOWLEDGEMENTS}

The work has been supported by the grant no. 206/93/2256 of the Grant Agency of the Czech Republic "Biotic interactions during vegetation succession on toxic substrates", grant no. 200/1997/B/BIO of the Grant Agency of Charles University and by the research project MSM 113100004, chapter "Ecological plasticity and taxonomical variability of expansive plant species“" of the Czech Ministry of Education.

\section{REFERENCES}

Bryndová, I., Kováŕ, P. (2004). Dynamics of the demographic parameters of the clonal plant Calamagrostis epigejos (L.) Roth in two kinds of industrial deposits (Abandoned sedimentation basins in Bukovina and Chvaletice). - In: Kovár̆, P., (ed.): Natural Recovery of Human-Made Deposits in Landscape (Biotic Interactions and Ore/Ash-Slag Artificial Ecosystems) (pp. 267-276).- Academia, Prague

Dlouhá, V. (1999). Functions of dead organic matter in primary succession on abandoned ore washery sedimentations basin in Chvaletice. - Ms. [Dipl. Thesis, Department of Botany, Charles University, Praha]. [in Czech]

Ebregh, A., Boldewijn, J.A.A.M. (1977). Influence of heavy metals in spruce forest soil on amylase activity, $\mathrm{CO}_{2}$ evolution from starch and soil respiration. - Plants and Soil, 47: pp. 137-148.

Evans, R.D., Johansen, J.R. (1999). Microbiotic crusts and ecosystem processes. - Crit. Rev., Plant Sci., 18(2): pp. 183-225.

Ewing, A.L., Engle, D.M. (1988). Effects of late summer fire on tallgrass prairie microclimate and community composition. - Am. Midl. Nat., 120: pp. 212-223.

Frouz, J., Prach, K., Pižl, V., Háněl, L., Starý, J., Tajovský, K., Materna, J., Balík, V., Kalčík, J., Řehounková, K. (2008). Interactions between soil development, vegetation and soil fauna during spontaneous succession in post mining sites. - European Journal of Soil Biology. 44: pp. 109-121.

Grigal, D.F., McColl, J.G. (1977). Litter decomposition following forest fire in northeastern Minnesota. - J. Appl. Ecol., 14: pp. 531-538.

Herranz, J.M., Martinez-Sanchez, J.J., Des Las Heras, J., Ferrandis, P. (1996). Stages of plant succession in Fagus sylvatica L. and Pinus sylvestris L. forests of Tejera Negra Natural Park (central Spain), three years after fire. - Israel J. Plant Sci., 44: pp.347-358.

Hroudová, Z., Zákravský, P. (2004). The influence of the moss layer on soil surface microclimate in an abandoned ore-washery sedimentation basin. - In: Kovár, P., (ed.): Natural Recovery of Human-Made Deposits in Landscape (Biotic Interactions and Ore/Ash-Slag Artificial Ecosystems) (pp. 235-247).- Academia, Prague

Hurlbert, L.C. (1969). Fire and litter effects in undisturbed bluestem prairie in Kansas. Ecology, 50: pp. 874-877. 
Jarešová, I., Kováŕ, P. (2004). Interactions between ants and plants during vegetation succession in the abandoned ore-washery sedimentation basin in Chvaletice. - In: Kovár, P., (ed.): Natural Recovery of Human-Made Deposits in Landscape (Biotic Interactions and Ore/Ash-Slag Artificial Ecosystems) (pp. 300-310).- Academia, Prague

Kováŕ, P. (1979). Geobotanical aspects of the sedimentation pond reclamation after pyrite processing near surface mining at Chvaletice. - Práce a Studie - Př́r. 11: pp. 63-78.[in Czech]

Kováŕ, P. (1990). Ecotoxicological contamination processes: Interaction with vegetation. Folia Geobot. Phytotax. 25: pp. 407-430.

Kovár, P. (2004). Industrial deposits of abandoned sedimentation basins - technology of the origin and vegetation. - In: Kováŕ, P., (ed.): Natural Recovery of Human-Made Deposits in Landscape (Biotic Interactions and Ore/Ash-Slag Artificial Ecosystems) (pp. 15-29). Academia, Prague

Kovář, P., Štěpánek, J. et Kirschner, J. (2004). Clonal diversity of Calamagrostis epigejos (L.) Roth in relation to type of industrial substrate and successional stage. - In: Kovář, P., (ed.): Natural Recovery of Human-Made Deposits in Landscape (Biotic Interactions and Ore/Ash-Slag Artificial Ecosystems) (pp. 285-293). - Academia, Prague

Kováŕ, P., Štefánek, M., Mrázek, J. (2011). Responses of vegetation stages with woody dominants to stress and disturbance during succession of abandoned tailings in cultural landscape. - Journal of Landscape Ecology 4(2): pp. 35-48.

Kovář, P., Vojtíšek, P. et Zentsová, I. (2012). Ants as eco-engineers in natural restoration of human made habitats. - In: Proc. of the 8th European Conference on Ecological Restoration - Extended Abstracts, September 9-14, 2012, České Budějovice (in press).

Kovářová, M., Frantík, T. (2004). Decomposition of organic matter on different substrates - laboratory study. - In: Kovář, P., (ed.): Natural Recovery of Human-Made Deposits in Landscape (Biotic Interactions and Ore/Ash-Slag Artificial Ecosystems) (pp. 153-175). Academia, Prague,

Kubíková, J. (1971). Geobotanické praktikum. Státní pedagogické nakladatelství, Praha. [in Czech]

Lepš, J. (1996). Biostatistics. - South Bohemian University, České Budějovice. [in Czech]

Medonosová, E. (1984). Decomposition of plant matter at high concentration of lead in the environment. - Ms. [Dipl. Thesis, depon. in Library of the Department of Botany, Charles University, Benátská 2, Praha 2]. [in Czech]

Neustupa, J., Škaloud, P., Peksa, O., Kubátová, A., Soldán, Z, Černá, K., Prášil, K., Bukovská, P., Vojta, J., Pažoutová, M., Veselá, J., Škaloudová, M. (2009). The biological soil crusts in Central European ecosystems, with special reference to taxonomic structure and ecology of the surface crusts at Czech ore-waste and ash-slag sedimentation industrial basins. - Novitates Botanicae Universitatis Carolinae, 19/2008: pp. 9-99.

Palice, Z., Soldán, Z. (2004). Lichen and bryophyte species diversity on toxic substrates in the abandoned sedimentation basins of Chvaletice and Bukovina. - In: Kovář, P., (ed.): Natural Recovery of Human-Made Deposits in Landscape (Biotic Interactions and Ore/Ash-Slag Artificial Ecosystems) (pp. 200-221). - Academia, Prague,

Pohlová, R. (2004). Changes on microsites of the moss Ceratodon purpureus and lichens Peltigera didactyla and Cladonia sp. div. in the abandoned sedimentation basin in Chvaletice. - In: Kovár̆, P., (ed.): Natural Recovery of Human-Made Deposits in Landscape 
(Biotic Interactions and Ore/Ash-Slag Artificial Ecosystems) (pp. 222-234). - Academia, Prague

Prach, K., Pyšek, P. (1994). Spontaneous establishment of woody plants in Central European derelict sites and their potential for reclamation. - Restoration Ecology, 2: pp. 190-197.

Prach, K., Bastl, M., Konvalinková, P., Kovář, P., Novák, J., Pyšek, P., Řehounková, K., Sádlo, J. (2008). Vegetation succession in human-made habitats in the Czech Republic survey of dominant species and stages - Príroda, 26: pp. 5-26. Praha.

Rauch, O. (2004). Genesis and characteristics of orewaste sulphate soils at Chvaletice. - In: Kovár,, P., (ed.): Natural Recovery of Human-Made Deposits in Landscape (Biotic Interactions and Ore/Ash-Slag Artificial Ecosystems) (pp. 45-58). - Academia, Prague

Spěváková, K. (2004). Degradation of plant litter and cellulose by microscopic fungi in an abandoned sedimentation basin. - In: Kováŕ, P., (ed.): Natural Recovery of Human-Made Deposits in Landscape (Biotic Interactions and Ore/Ash-Slag Artificial Ecosystems) (pp. 147-152). - Academia, Prague

Singh, N. (1977). Effect of $\mathrm{pH}$ on the tolerance of Penicillium nigricans to copper and other heavy metals. - Mycologia, 69: pp. 750-755. [in Czech]

Sufling, R., Smith, D.W. (1974). Litter decomposition studies using mesh bags: spillage inaccuracies and the effects of repeated artificial drying. - Can. J. Bot., 52: pp. 2157-2163.

Štefánek, M. (1999). Restoration of vegetation in the abandoned sedimentation basin after the disturbance. - Ms. [Dipl. Thesis, Department of Botany, Charles University, Praha]. [in Czech]

Tesařová, M. (1987). Determination of decomposition rate of the plant organic matter by litter-bag method. - In: Rychnovská, M., et al., (eds.): Methods of study of grassland ecosystems. (pp. 187-190). - Academia, Praha, [in Czech]

Vaňková, J., Kovář, P. (2004). Plant species diversity in the biotopes of un-reclaimed industrial deposits as artificial islands in landscape. - In: Kovár, P., (ed.): Natural Recovery of Human-Made Deposits in Landscape (Biotic Interactions and Ore/Ash-Slag Artificial Ecosystems) (pp. 30-45). - Academia, Prague

Vos, C.C., Opdam, P., (eds.) (1993). Landscape ecology of a stressed environment. Chapman \& Hall, London.

Williams, S.T., Gray, T.R.G. (1974). Decomposition of litter on the soil surface. - In: Dickinson, C.H., Pugh, G.J.F., (eds.): Biology of plant litter decomposition, (pp. 611-632). Volume 2. Academic Press, London and New York, 